Recepción: 23 / 02 / 2018

Aceptación: 17 / 04 / 2018

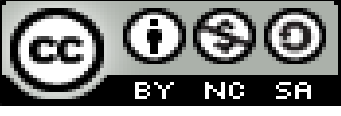

Ciencias de la educación

Publicación: 01 / 08 / 2018

Artículo de investigación

\title{
Calidad pedagógica desde las redes informáticas manejadas en el sistema de
} educación universitario

Pedagogical quality from the computer networks handled in the university education system

Qualidade pedagógica das redes de computador handled no sistema de educação universitária

\author{
Jorge T. Carrión-González I \\ jtuliocg@gmail.com \\ Cristian S. Sancho-López II \\ cs_s10@hotmail.com \\ Marcia M. Aguirre-Ochoa III \\ maribelaguirre24@hotmail.com
}

\section{Correspondencia: jtuliocg@gmail.com}

\footnotetext{
${ }^{I}$ Magister en Redes de Comunicaciones, Ingeniero Comercial, Ingeniero en Sistemas, Pontificia Universidad Católica del Ecuador, Quito, Ecuador.

II Ingeniero de Sistemas, Universidad Técnica de Machala, Machala, Ecuador.

${ }^{\text {III }}$ Magister en Gerencia y Liderazgo Educacional, Ingeniera de Sistemas, Licenciada en Ciencias de la Educación Especialización Informática, Universidad Técnica Particular de Loja., Loja, Ecuador.
} 


\section{Resumen}

El propósito de este artículo es evaluar la calidad pedagógica de las plataformas virtuales en la educación universitaria ecuatoriana. La investigación siguió un enfoque cuantitativo con una tipología descriptiva y un diseño no experimental, de campo - transaccional. La población estuvo conformada por estudiantes de las Universidades adscritas al cantón de Loja. La información se obtuvo a partir de la aplicación de un instrumento con una escala ordinal que presenta un conjunto de afirmaciones conformado por 38 ítems, el cual fue sometido a la validación por expertos y de constructo, y su confiabilidad fue de 0.86 considerado altamente confiable. Para el análisis de la información se utilizó la estadística descriptiva. Entre sus resultados, se destaca el hecho en la cual las propuestas pedagógicas y curriculares de las plataformas educativas virtuales y el estudio de las necesidades de los usuarios fueron evaluadas de regular a buena; también el abordaje de los problemas en materia de informática y el desarrollo de proyectos vía web fueron considerados como los más acordes. Entre sus conclusiones, se pudo valorar como excelente, por parte de los investigados, el proceso de mediación de las plataformas virtuales y los criterios de evaluación de su calidad.

Palabras Clave: calidad; pedagogía; redes informáticas; enseñanza.

\section{Abstract}

The purpose of this article is to evaluate the pedagogical quality of virtual platforms in Ecuadorian university education. The research followed a quantitative approach with a descriptive typology and a non - experimental, field - transactional design. The population was conformed by students of the Universities attached to the canton of Loja. The information was obtained from the application of an instrument with an ordinal scale that presents a set of affirmations consisting of 38 items, which was subjected to validation by experts and construct, and its reliability was 0.86 considered highly reliable. For the analysis of the information, descriptive statistics were used. Among its results, the fact stands out in which the pedagogical and curricular proposals of the virtual educational platforms and the study of the needs of the users were evaluated from regular to good; also the approach of the problems in the matter of informatics and the development of projects via web were considered as the most agreed. Among its conclusions, the mediation process of the virtual platforms and the criteria for evaluating their quality could be assessed as excellent by the researchers. 
Keywords: quality; pedagogy; computer networks; teaching.

\section{Resumo}

O objetivo deste artigo é avaliar a qualidade pedagógica de plataformas virtuais na educação universitária equatoriana. A pesquisa seguiu uma abordagem quantitativa com uma tipologia descritiva e um desenho não - experimental transacional de campo. A população foi conformada por estudantes das Universidades ligadas ao cantão de Loja. As informações foram obtidas a partir da aplicação de um instrumento com uma escala ordinal que apresenta um conjunto de afirmações composto por 38 itens, que foi submetido à validação por especialistas e construto, e sua confiabilidade foi de 0,86 considerada altamente confiável. Para a análise das informações, utilizou-se estatística descritiva. Entre seus resultados, destaca-se o fato de que as propostas pedagógicas e curriculares das plataformas educacionais virtuais e o estudo das necessidades dos usuários foram avaliados de regular para bom; também a abordagem dos problemas em matéria de informática e o desenvolvimento de projetos via web foram considerados os mais acordados. Entre suas conclusões, o processo de mediação das plataformas virtuais e os critérios para avaliar sua qualidade poderiam ser avaliados como excelentes pelos pesquisadores.

Palavras chave: qualidade; pedagogia; redes de computadores; ensinando 